\title{
ECO-ENTREPRENEURS ORGANIZATIONAL ATTITUDE TOWARDS SUSTAINABLE COMMUNITY ECOTOURISM DEVELOPMENT
}

\author{
Harshavardhan Reddy KUMMITHA
}

Budapest Business School, University of Applied Sciences, Budapest-1055, Hungary, harshavardhankummitha@gmail.com

Cite this article: Kummitha, H.R. (2020). Eco-Entrepreneurs Organizational Attitude towards Sustainable Community Ecotourism Development. Deturope, 12(1), 85-101.

\begin{abstract}
Ecotourism is one of the most popular sectors in the modern tourism industry. Eco-entrepreneurship is a recent development in entrepreneurial society. These two sectors together attempt to solve the environmental and socio-economic problems. This paper analyzes eco-entrepreneurs organizational factors for community ecotourism development in the case of Kabani community ecotourism organization. The study comprised of both secondary and primary data. For primary data, the author conducted a field study research with community members of a small-scale eco-entrepreneurial organization, Kabani Community Tourism between October to December 2017. For secondary data, the author engaged in an extensive literature review process to identify eco-entrepreneurship research conducted in the tourism industry. Quantitative primary data were collected through questionnaires among 56 local communities employed by Kabani ecotourism organization. The well-known classified technique, Principle Component Analysis has been performed to find the factors of eco-entrepreneurship organization for local communities development. These factors are named as a social, economic, and environmental development factors. Findings show that local communities see eco-entrepreneur organizational factors socio-economic, environmental and local communities age and environmental educational awareness programmes influence the development of ecotourism.
\end{abstract}

Key words: Ecotourism, Sustainability, Destination development, Eco entrepreneurship, Community development.

\section{INTRODUCTION}

Entrepreneurs have been classified based upon their motivation towards their business model within their sector of interest. This type of entrepreneurship varies by location and propose of the business (Yaşar and Cemile, 2018). In recent years, countries are increasingly concerned about Environmental awareness programmes and this awareness activates given increasingly influenced by entrepreneurs (Tol, 2018). This type of entrepreneurs referred to as green or ecoentrepreneurs. Mostly Eco entrepreneurship has emerged as a topic, and it has become an increasingly popular field of tourism research since the late 1990s. Eco-entrepreneurs are small scale business sectors of the tourism industry, and their main motivation for the business is to protect the environment and sustain the economic well-being of local communities. Eco entrepreneurs not only fulfill the economic goals of local communities but also solve the 
environmental problems (Lordkipanidze et al. 2005; Dean \& McMullen. 2007; Buzinde et al. 2017).

The concept of environmentally responsible entrepreneurial business activities is a relatively new approach in the tourism sector. However, there have been a small number of organizations, and business communities familiar with this concept. Academically, this term was first introduced in 1990. The concept of eco-entrepreneurship is a combination of two words eco (environmental) and entrepreneurship, which implies the creation of an innovative organization that supplies environmentally friendly products or services (Schaper, 2002). Ecotourism is one of the fastest-growing sectors in tourism industry with annual 5\% growth rate (TIES, 2019), Ecotourism, and eco- entrepreneurship both sectors having the same policies of environmental protection and improving the socio-economic conditions of local communities in a sustainable way. Unfortunately, there is insufficient research done in the field of eco-entrepreneurs maintaining ecotourism destinations.

This paper aims to identify the key factors of eco-entrepreneurs for development of ecotourism. The paper looks at research based on the conservative environmental approach in the framework of eco-entrepreneurship and their process of developing a tourist destination. This research focuses on the eco-entrepreneur's business model for creating sustainability in a tourist destination. Kabani ecotourism was selected as the case study. The essential elements of this paper include business strategies used by the Kabani organization to deal with the local communities' social, economic, and environmental challenges.

\section{BACKGROUND}

The tourism industry has attained significant growth in the recent past, And the need to assess its contribution to larger sustainable development discourse has gained momentum. Tourism as an industry accounts for about 10 percent of the total global GDP (Hirotsune, 2011). According to the United Nations World Tourism Organization (UNWTO, 2019), international tourism arrivals are growing 5\% in 2018 to reach 1.4 billion marks. It is further estimated that by 2030 international tourist arrivals will grow 1.8 billion tourists. Especially, ecotourism within the larger tourism industry has witnessed the fastest growth with an annual growth rate of 5 percent worldwide (TIES). This has been promoted by the national government initiating policies in support of ecotourism (Das, 2011). The reason for the growth and policy emphasis on ecotourism should be credited to its growing popularity in international discourse of achieving sustainable development. Ecotourism addresses the environmental concern that many 
sustainable development debates talk about. Ecotourism had become quite evident in both policy and practices since 1994, especially when the commission on sustainable development of United Nations organization incorporated the approach of 'sustainable nature-based tourism' (Das, 2011).

There is a growing trend that eco entrepreneurship, which traditionally aims to address economic and environmental problems, has now started to investigate tourism as a potential area in order to enhance local potential (Tetzschner \& Herlau, 2003). Schumpeterian theory and ecological modernization theory provide the theoretical view of eco entrepreneurship. According to (Schumpeter, 1942; Hajer, 1995; Mol, 1996), entrepreneurs are innovators, and they give society a modern way of addressing the problem. In the 1990s, authors began examining and discussing the term environmental entrepreneurship. This kind of entrepreneurs is motivated by the economic growth of a tourist destination, as well as by the protection of the environment (Tillery \& Young, 2009). Eco-entrepreneurs seek to take business ventures which involve environmental and economic risks. The outcomes of these ventures are never predictable, but there is a higher possibility of failure in eco-friendly business than in a standard business venture (Dees, 2017). The success of an eco-entrepreneurs business relies on the enterpreneurs' ability to develop sustainable solutions to environmental issues. Social science scholars argue that modernization and globalization focused entrepreneurs act to avoid societal problems by instead focusing on strictly business issues (Tillery \& Young, 2009; Mol, 1996). These entrepreneurs enact the best solutions to their business problems, but this does not always take the environment, or even social issues, into consideration. According to (The Sustainable Mobility Report 2002) by WBCSD the earth's human population is expected to increase by half $(50 \%)$ by 2050 , and with that increase comes the need for more consumption. Ecoentrepreneurs are tasked with finding better solutions to the consumption of natural resources to ensure that they are enough to fulfil the needs of current and future generations (McEwen, 2013). Both ecotourism and eco-entrepreneurship are recent additions to their respective fields. These two sectors are capable of solving social, economic, and environmental problems, especially those related to nature, tourism and local economies, and sustainable development. Anecdotal evidence shows that ecotourism and eco-entrepreneurship have been successful in these areas. However, there has not been enough research carried out in these areas. Particularly lacking is the research of a larger scope, to assess various eco-entrepreneurs organizational factors involvement for enhancing local community participation for sustainable ecotourism development. 


\section{The concept of eco-entrepreneurship in ecotourism}

The International Ecotourism Society (TIES) defines ecotourism as "responsible travel to natural areas that conserves the environment and improves the well-being of local people and involves interpretation and education" (TIES, 2015). Ecotourism is about uniting the environment, communities, and sustainable travel. An eco-tourist spends more time and money in travel than any other type of tourist (Scheyvens, 1999). Ecotourism has emerged as one of the key areas of involvement for eco-entrepreneurs as they focus on changing the industry in order for nature, tourists, and communities to benefit equally from the practices (Shaper, 2002). Eco-entrepreneurs aim to address unsolved environmental problems, and they work to achieve their dual-purpose, which includes both social and financial, and environmental value creation (Shaper, 2002). The practice of social entrepreneurship broadly encompasses a business model that non-profit entities adopt while addressing social issues. Through this process, ecoenterprises rely heavily on market-based approaches and income generation activities (Lehner, 2011). It is understood that neither non-profit organizations, which lack sufficient resources and skills, nor the industry that is investor-owned, which aims at generating profits alone, would be able to address these environmental issues unless institutions shift their focus (Dees, 2017).

In the early 1990s authors such as (Bennett, 1991; Berle,1991; Blue, 1990), coined terms such as 'green entrepreneur', environmental entrepreneur', and 'eco-entrepreneur,' which has been shortened to just 'ecopreneur'. The mid-1990s the ecopreneur concept being more closely examined by (Anderson \& Leal, 1997; Andersen, 1998; Keogh and Polonsky, 1998; Hostager et al., 1998; Adeoti, 2000; Larson, 2000; Kyrö, 2001). Their works served to form the basis of the modern conception of eco-entrepreneurship. The recent innovation of this research include works by (Walley \& Taylor, 2002; Schaltegger, 2002; Pastakia, 2002; Seelos \& Mair, 2005; Cohen \& Winn, 2007; Dean \& McMullen, 2007). The field of academic papers on ecoentrepreneurship is still growing, though one of the most influential papers is by (Schaper, 2002) which discusses emulating the eco-entrepreneurs way of solving environmental issues in a sustainable manner. Proper practice of eco-entrepreneurship means that every product, service, organization or technology must simultaneously address an environmental issue and allow for sustainable economic growth and development (York et al. 2016).

Practicing eco-entrepreneurship does not demand the creation of a brand-new venture. Finding an innovative way of managing existing organizations in order to enhance social wealth 
is a form of eco-entrepreneurship (Zahra et al. 2009). Eco entrepreneurship may be exercised by a person, or a group of persons having some kind of environmental value that is attained through their actions (Schaper, 2002). The creation of pro-environmental value may refer to attaining 'environmental protection, social mobility, the reduction of environmental exclusion, social innovation leading to social and environmental sustainability and even societal transformation' (Hill et al., 2010). This brings us a holistic understanding of the perpetual intentions and the range of activities that these hybrid organizations undertake. It is to be understood from the discussion that the main concern for eco-entrepreneurship is to address the problems of both environment and communities.

\section{Eco-entrepreneurship and community development}

When it comes to ecotourism, Richards and Hall, (2003) opinion is that communities are one of the basic reasons for tourists to travel to experience their way of life as well as to learn how communities shape the natural landscape. Hence, it is necessary to consider communities while undertaking any planning related to the development of tourist destinations. Thus, both ecotourism and eco entrepreneurship operate in a similar fashion when it comes to addressing the needs of the communities and requiring their participation in the decision-making process.

The participation of rural communities in ecotourism industry has been a focus in its development since 30 years. Stone \& Stone, (2011); Richards and Hall, (2003) believe that active local participation in decision-making is some benefits to make local communities wellbeing economically. However, this has difficult to practice in many very developing countries because of various Cultural barriers. Community participation is, moreover, advocated for environmental reasons as well as for more sustainable development (Van Rooyen, 2004). Unless local communities are empowered and participate fully in decision-making and ownership of tourism development activities, tourism will not affect their values and will less likely generate sustainable outcomes (Ansari et al. 2012).

According to Stronza (2007), community participation in ecotourism development the way for the implementation of principles of sustainable tourism development and creates better opportunities for local communities to gain more benefits from tourism developments taking place in their rural areas. Moreover, those benefits need not always be financial. Often the intangible benefit of skills development, increased confidence, growing trust, and ownership of 
the destination may be of greater value to the community and environmental conservation (Ansari et al. 2012).

According to Tosun (2000), "community participation in ecotourism destination development is a unique type, involves a shift in power from those who have had major decision-making to those who traditionally have not had such a role in maintaining the organizational maintenance. One of the basic principles of ecotourism is that it should be both economically viable for business entrepreneurs and should provide good well-being to the local communities. The profitability conditions of ecotourism are to develop ecotourism as so to decrease the costs of ecotourism to the host community and environment Stronza (2007).

Perhaps the most efficient opportunity to local communities is through employment in and income from the ecotourism industry itself. Besides employment, other benefits of ecotourism include diversification of the local economy, increases in local markets of agriculture and local products, and improved accessibility of the destination. According to Tosun (2000), local communities can become involved in various ecotourism destination development and in getting knowledge about environmental sustainability.

It is clearly understood from the above discussion that there are many advantages to incorporate local involvement in ecotourism development. According to Ansari et al. (2012) community involvement provides a better understanding of environmental situation between attractors and service businesses, promises greater community through avoiding social, environmental and economic problems, moreover reduces entrepreneurs failures by assuring environmental and community acceptance of ecotourism and assists in obtaining needed human and financial resources. (Van Rooyen, 2004)

\section{Sustainable ecotourism development}

The concept of Sustainability has become increasingly important to tourism scholars. Debates about how the sector engages with the concept are unclear inextricably linking to sustainable development. Tilley \& Young (2009), have suggested that sustainable tourism incorporates most of the key features of sustainable development. During the late $19^{\text {th }}$ century, the sustainable development approach to tourism development was advanced by several authors (Butler, (1991); Garcia-Ruiz et al., (1996); Hall, (1998)). Most authors agreed that the concept of sustainable tourism development is effective for tourism development with environmental and social responsibility. 'Its aim is to meet the needs of the present tourists and host regions 
while protecting and enhancing environmental, social, and economic values for the future'. Sustainable tourism development leads to entrepreneurial action of all resources in such a way that it can fulfil economic, social, and environmental needs while fulfilling the cultural integrity, essential ecological processes, biological diversity, and life support systems Hall, (1998). As a result, the concept of sustainability has become a mediating term between economic and political differences between the environmental and development lobbies, a bridge between the fundamentally opposed paradigms of eco and anthropocentrism (Wearing \& Neil,1999).

According to TIES Goals of sustainability are outlined as:

- To improve greater awareness and understanding of the significant contributions. that ecotourism can make to the environment and the economy,

- To promote equity in development of destination,

- To improve the quality of life of the Local community,

- To provide a high quality of experience for the visitor, and to maintain the quality of the environment on which the foregoing objectives depend.

\section{ABOUT CASE STUDY SITE}

Thrikkaipetta is a picturesque village associated with the Kabani ecotourism society in the hilly district of Wayanad, in north Kerala. Being in the middle of hills, and located at a moderate altitude, climate in this village is pleasant throughout the year. With Manikkunnu hills and endless paddy fields as backdrop, this place calms your mind with its many shades of green. Thrikkaipetta is well known for its spiritual tourism, rich folklore, and numerous art and craft units. This place is also an ornithologist's paradise with more than 140 winged beauties. You can find a wide variety of plant cultivations and spice plantations here including pepper, coffee, tea, cardamom, nutmeg, areca nut, etc.

Kabani Eco Tour manages a host families network, which has really a positive impact on many villagers' lives. Tourism revenues are shared between service providers (guides, taxi drivers, etc.), administrators, and a village development fund monitored by a village committee. Moreover, this organization collaborates with a local organization called Uravu Eco Links to provide better service to tourists as well as local communities. This organization chose to focus on ecotourism because of the region's large potential tourism market. In addition, two other development projects were adopted: organic agriculture and renewable energy. The presence 
of this organization was used to introduce and experiment with market-based mechanisms as alternative means for promoting economic development and conservation in this economically impoverished, but biologically rich region of Wayanad wildlife sanctuary.

Figure1 Location of the Kabani ecotourism organization study area.

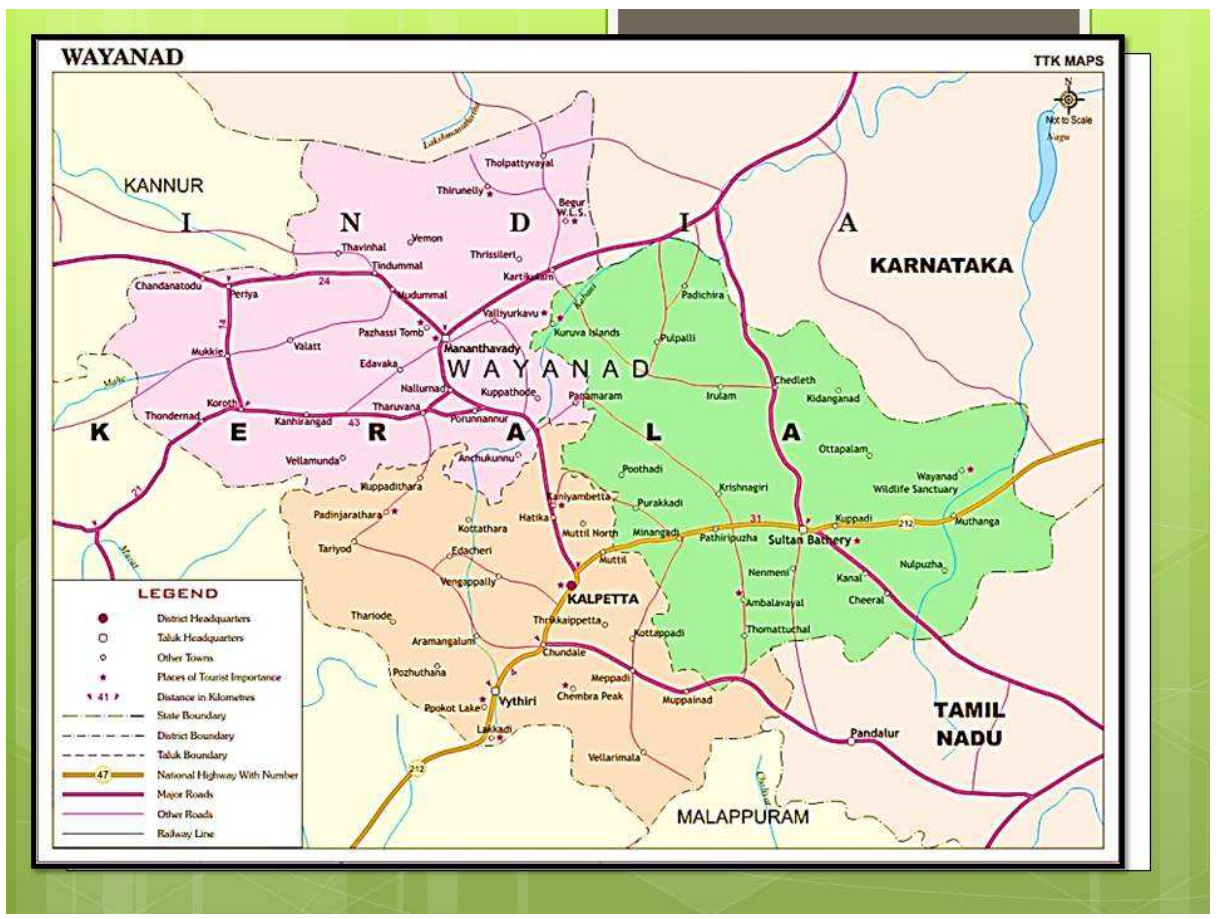

Source: Tourism ministry of Indian, Kerala tourism.

\section{A Unique and Balanced Combination of Opposing and Proposing Sides of Kabani}

The opposition to Kabani is seeking political change in the current paradigm of development in ecotourism. A regulatory framework to oversee sustainable tourism is important and demands changes in the current environmental policy. The interests of small and community tourism players are often neglected in existing policies and it is important for these policies to be altered to protect those interests. Kabani has successfully intervened and lobbied for policy changes at various levels and helped local communities to protect their rights, as can be seen in the case of the post tsunami project empowerment of coastal communities in south India for tourism policy interventions. Kabani helped thousands of marginalized people in the coastal communities of Kerala and Tamil Nadu. There are 2,100 primary beneficiaries of the project along with 296,673 indirect beneficiaries. Kabani helped them to defend their rights by training and empowering the community to intervene in tourism policies and planning. 
On the proposing side, Kabani leaves a positive impact on the lives of many families by facilitating community tourism in Indian villages. Through KABANI-Community tourism \& Service, the company promotes homestays, which help local communities to earn additional income. It is especially important during times of crisis, such as the aftermath of the 2004 tsunami, as well as during crises in agriculture, where many farmers in Wayanad district had committed suicide due to declining prices and the impact of climate change on their crops. To diversify their livelihood options, farmers started their own homestays with training and marketing help from Kabani. This enabled them to sustain themselves and their agricultural activities.

\section{METHODS}

I adopted a quantitative research approach to achieve the objective of the paper. Highlighting the study on eco entrepreneurship organizational ecotourism communities development in Indian context. I selected Indian eco-entrepreneurship organization as a suitable setting because of three reasons: First one India has the highest number of entrepreneurs activities in different business sectors described by Asoka foundation (Kummitha and Majumdar,2015). Second, there is a significant growing demand in ecotourism destinations among domestic and international tourist in India (Das and Chatterjee, 2015). Thirdly there is lack of eco entrepreneurship organizational initiative in India due to lack of awareness about entrepreneurs business activities (Intellecap,2012). I initially searched eco entrepreneurship organizations for ecotourism development as part of my Doctoral research field work in India and found that there are 12 eco- entrepreneurship organizations who are having community development as their business approach. Among them, I chose kabnai community ecotourism organization as my case study for this paper.

Field work for this study was conducted in Kabani community ecotourism organization between October to December 2017. The aim was to identify the eco- entrepreneurship organizational components, which is helpful for local communities development in Kabani community entrepreneurship organization. The tool for the collection of data was divided into two parts: socio-economic demographics of local communities and Eco entrepreneurship support for tourism development. There are 15 variables used to determine the local community's perception of eco-entrepreneurship organizations were adapted from (Muresan et 
al. 2016). A 5 point Likert- type scale used during collection of data based on the following scale: 1- strongly disagree,2- disagree, 3- natural, 4- agree, 5- strongly agree. Data were collected from 56 local community members employed by Kabani ecotourism organization. The response rate was $100 \%$, and in the end 54 questionnaires were validated.

Descriptive statistics were used to analyze the socio- economic demographics profiles of local communities and to describe the local communities perception towards eco-entrepreneurs ecotourism development. Factor analysis was used to assess the factors structure of the variables. Principle component analysis (PCA) were conducted to identify the group of perception variable about eco entrepreneurship tourism development.

\section{RESULTS AND DISCUSSION}

\section{Local communities Demographics}

Local communities' demographics are presented in the table below. Based on the sample, there were more males $(64.4 \%)$ than females $(35.6 \%)$. The youngest community member was 19 years old and the oldest was 62 years. Within the age group, $17.1 \%$ belong to $15-25$, and the age group 25- 40 consider as the largest age group within the local community with $40 \%$ of total sample. The 40-50 age group consider as second largest and had 26.7\% of total respondents. Local communities with over 50 years consider as oldest represented $16.2 \%$ of the total sample. When it comes to education, most of the respondents complected from high school studies (43.3\%), and 30\% of the respondents are school leave graduation. The remaining $26.7 \%$ of respondents had no formal schooling indicating a lack of educational awareness in rural areas.

The annual household income levels reported are less than 500 Euro (30000 INR) (52.2\%), 500-850 Euro (30000-60000 INR, 32.5\%), and more than 1000 Euro (75000 INR, 15.5\%), while the average family number is 3.7 members. It can be dedicated that the local communities were less educated, with a low annual income. The results can mainly attribute eco entrepreneurship organizations could not provide enough employment opportunities for local communities due to limited social resources. Literacy levels also pose another problem in local communities destination development. 
Table 1 Characteristics of local communities

\begin{tabular}{|c|c|}
\hline Variables & $\%$ \\
\hline \multicolumn{2}{|c|}{ Gender } \\
\hline Male & 64.4 \\
\hline Female & 35.6 \\
\hline \multicolumn{2}{|c|}{ Status } \\
\hline Married & 20 \\
\hline Single & 78.9 \\
\hline others & 1.1 \\
\hline \multicolumn{2}{|c|}{ Age } \\
\hline $15-25$ & 17.1 \\
\hline $25-40$ & 40 \\
\hline $40-50$ & 26.7 \\
\hline$>50$ & 16.2 \\
\hline \multicolumn{2}{|c|}{ Education Qualification } \\
\hline School & 30 \\
\hline High School & 43.3 \\
\hline Illiterate & 26.7 \\
\hline \multicolumn{2}{|c|}{ Annual Household Income } \\
\hline$<30000$ INR & 52.2 \\
\hline 30000-60000 INR & 32.2 \\
\hline$>75000$ & 15.5 \\
\hline
\end{tabular}

Source: Author own creation based on primary data

\section{Factors of eco-entrepreneurs for ecotourism community development}

Principle factor analysis was conducted to assist the dimensionality of 15 variables. The KMO Bartlett's Test was also conducted to verify the normality and significance of the conducted analyses, and it was found to be significant at $(\mathrm{p}<0.05)$. Bartlett's Test of Sphericity (chi-square 88.043) The Kaiser-Meyer-Olkin (KMO) overall measure of sampling is 0.55 , indicating that this data is suitable to use the principal component analysis.

Table 2 Pattern matrix for identifying eco-entrepreneurs factors

\begin{tabular}{|l|l|l|l|}
\hline \multicolumn{1}{|c|}{ Variables } & \multicolumn{3}{|c|}{ Components } \\
\cline { 2 - 4 } & $\begin{array}{c}\text { Economic } \\
\text { Development }\end{array}$ & $\begin{array}{c}\text { Environmental } \\
\text { Development }\end{array}$ & $\begin{array}{c}\text { Social } \\
\text { Development }\end{array}$ \\
\hline $\begin{array}{l}\text { This organization provide full time employment } \\
\text { opportunity for local communities? } \\
\text { I have economic attachment with this organization and it }\end{array}$ & 0.551 & \\
improved economic conditions of my family \\
$\begin{array}{l}\text { Initiate good projects to solve the socio- economic } \\
\text { conditions of local communities and protect the } \\
\text { environment }\end{array}$ & 0.675 & \\
$\begin{array}{l}\text { Encourage local communities participation in planning } \\
\text { and decision making process of destination } \\
\text { development? }\end{array}$ & 0.785 & \\
\hline
\end{tabular}


Table 2 (continued)

\begin{tabular}{|c|c|c|c|}
\hline \multirow[t]{2}{*}{ Variables } & \multicolumn{3}{|c|}{ Components } \\
\hline & $\begin{array}{c}\text { Economic } \\
\text { Development }\end{array}$ & $\begin{array}{c}\text { Environmental } \\
\text { Development }\end{array}$ & $\begin{array}{c}\text { Social } \\
\text { Development }\end{array}$ \\
\hline Encourage local talent, arts and crafts in communities & 0.749 & & \\
\hline $\begin{array}{l}\text { Increased working opportunities during tourism } \\
\text { seasonality for local communities }\end{array}$ & 0.653 & & \\
\hline $\begin{array}{l}\text { I am willing to put all my efforts in this organization to } \\
\text { make my place better ecotourism spot }\end{array}$ & 0.659 & & \\
\hline $\begin{array}{l}\text { This organization will bring more development and more } \\
\text { tourist to your areas }\end{array}$ & 0.681 & & \\
\hline $\begin{array}{l}\text { Without Kabani organization your communities are able } \\
\text { to handle socio- economic and environmental problem of } \\
\text { the destination }\end{array}$ & 0.537 & & \\
\hline $\begin{array}{l}\text { What is your perception about role of eco entrepreneurs } \\
\text { organization programmes on sustainable development }\end{array}$ & & & \\
\hline $\begin{array}{l}\text { Encourage conservation of environmental and cultural } \\
\text { resource of the destination? }\end{array}$ & & 0.770 & \\
\hline $\begin{array}{l}\text { This Organization increases the support of conservation } \\
\text { for natural resource and provide environmental } \\
\text { education awareness to local communities }\end{array}$ & & 0.651 & \\
\hline $\begin{array}{l}\text { This organization provide alternative approach to mass } \\
\text { tourism without hurting the quality of destination? }\end{array}$ & & & \\
\hline $\begin{array}{l}\text { This organization encourage to hosting ecofriendly } \\
\text { events such as festivals }\end{array}$ & & & 0.725 \\
\hline $\begin{array}{l}\text { This organization promotes better infrastructural } \\
\text { facilities that bring tourist to your area? }\end{array}$ & & & 0.582 \\
\hline
\end{tabular}

Source: Author own creation based on primary data

The first factor assigned for Economic development total variance represented $29.6 \%$. The variables involved attributes related to local communities economic factors, such as encouraging local communities participation in planning and decision making process of destination development (0.785 Pattern Matrix), Encourages local talent arts and crafts in communities (0.749 Pattern Matrix), Economic attachment with the organization and its improvement of economic conditions of families (0.712 Pattern Matrix). The second factor was assigned for environmental development and it is represented $12.4 \%$ variance. The variables involve attributes related to environmental development of eco entrepreneurs sustainable development of the destination. This includes such as Encouraging conservation of environmental and cultural resource of the destination (0.770 Pattern Matrix), Local communities perception about role of eco entrepreneurship programmes for sustainable development (0.665 Pattern Matrix), Increasing the support of conservation for natural resource and provide environmental education awareness to local communities (0.651 Pattern Matrix). The third factor was assigned for social development and it is represented $9.63 \%$ variance. The 
variables attributes related to social development for destination, such as Provision of alternative approach to mass tourism without hurting the quality of destination (0.731 Pattern Matrix), Encouraging the to hosting of ecofriendly events such as festivals and (0.725 Pattern Matrix), promoting better infrastructural facilities to bring more tourists to your area (0.582). This result of the study is differing from other research, in that eco enterprises prioritizes community economic development and more environmental sustainability of the destination.

Table 3 Factor correlation Matrix

\begin{tabular}{|c|c|c|c|}
\hline Factor Correlation Matrix & $\begin{array}{c}\text { Correlation } \\
1\end{array}$ & Correlation 2 & $\begin{array}{c}\text { Correlation } \\
3\end{array}$ \\
\hline Economic development Factor & 1.000 & 0.226 & 0.108 \\
\hline Environmental development Factor & 0.226 & 1.000 & 0.131 \\
\hline Social development & 0.108 & 0.131 & 1.000 \\
\hline
\end{tabular}

Source: Author own creation based on primary data

The results of simple correlation matrix analysis on the support for economic tourism development for local communities and support for environmental tourism development for environmental conservation and support of social development for social benefits, based on Table (). The economic development highest correlation factor matrix. $1(1.000, \mathrm{P}<1)$, environmental development highest correlation factor matrix $2(1.000, \mathrm{p}<1)$, and social development highest correlation factor matrix $3(1.000, \mathrm{p}<1)$ were significantly correlated with support of eco entrepreneurship organizations for sustainable community development.

\section{CONCLUSION}

The objectives of this paper were to examine the Eco entrepreneurship attitudes factors towards community development and their influence on sustainable tourism development. The results of the study indicate that local communities perceive eco-entrepreneurs factors positively. And they believe eco entrepreneurship organizations are actively engaged towards sustainable development of the destination. Environmental development factors are considered most important for sustainable development. The fact is that eco-entrepreneurs give importance to conservation for natural resources and provide environmental education awareness to local communities, on the one hand, and reduce the mass tourism destination in development on the other hand.

Eco entrepreneurs improve the quality of life of residents due to its effect on economic development of the area, which in turn to lead employment opportunities for local communities; 
furthermore, communities benefit from alternative recreational activates and the improvement of the infrastructure of the destination.

Findings show that eco-entrepreneurs organizational impacts are positively encouraged by local communities. They see that tourism is an income-generating activity and increases well-being. Most importantly, the local population encourages sustainable tourism methods adopted by ecoentrepreneurs; at the same time, they are understanding the importance of decision making and managing the destination on a sustainability basis.

This study reveals the lack of residence environmental awareness toward sustainable tourism development in a rural area of India, especially the study site in Kerala. The Indian state of Kerala eco-entrepreneurs approaches are a new concept towards sustainable tourism development with RTI (Right to information act) initiative (Kerala ecotourism policy 2012), however due to this policy of sustainable development cannot be implemented on the entire state (Thimm, 2017). Over time lack of consistent and reliable information regarding local residents' attitudes towards sustainable rural development has negatively influenced the decision-making process regarding the sector's funding allocation. In the words of (Veron, 2011) the concept of sustainable development has not yet become a general cultural value in Kerala. Like anywhere else, people in Kerala tend to prioritize their own immediate economic and social benefits (Veron, 2011). The findings of this paper can be contributing to eco entrepreneurship organizational attributes improve the ecotourism development, such as changing the rural residents way of thinking about sustainable rural tourism development.

\section{Acknowledgement}

The author would like to thank two anonymous reviewers for helpful comments and critical advice.

\section{REFERENCES}

Adeoti, J.O. (2000). Small Enterprise Promotion and Sustainable Development: An Attempt at Integration. Journal of Developmental Entrepreneurship, 5(1), 57-71.

Anderson, A.R. (1998). Cultivating the Garden of Eden: environmental entrepreneuring. Journal of Organizational Change Management, 11(2), 135-144

Anderson, T.L. and D.R. Leal (1997) Enviro-Capitalists: Doing Good While Doing Well, Rowman \& Littlefield, Boston, MA, Published April 30th 1997 by Rowman \& Littlefield Publishers.

Ansari, S., Munir, K., \& Gregg, T. (2012). Impact at the 'bottom of the pyramid': The role of social capital in capability development and community empowerment. Journal of Management Studies, 49(4), 813-842.

Bennett, S.J. (1991) Ecopreneuring: The Complete Guide to Small Business Opportunities from the Environmental Revolution, Wiley, New York. 
Berle, G. (1991) The Green Entrepreneur: Business Opportunities That Can Save the Earth and Make You Money Liberty Hall Press, Blue Ridge Summit, PA. Liberty Hall Press.

Blue, J. (1990) Ecopreneuring: Managing for Results, Scott Foresman, London.

Butler, R. W. (1991). Tourism, environment, and sustainable development. Environmental conservation, 18(3), 201-209.

Buzinde, C., Shockley, G., Andereck, K., Dee, E., \& Frank, P. (2017). Theorizing social entrepreneurship within tourism studies. In Social Entrepreneurship and Tourism (pp. 2134). Springer, Cham.

Cohen, B. \& Winn, M.I. (2007). Market Imperfections, Opportunity and Sustainable Entrepreneurship. Journal of Business Venturing, Vol. 22 No. 1 (January), pp. 29-49.

Das, M., \& Chatterjee, B. (2015). Ecotourism and Empowerment: A Case Analysis of Bhitarkanika Wildlife Sanctuary, Odisha, India. IIM Kozhikode Society \& Management Review, 4(2), 136-145.

Das, S., (2011). Ecotourism, Sustainable Development and the Indian State, in Economic and Political Weekly, XLVI (37), 60-67.

Dean, T. J., \& McMullen, J. S. (2007). Toward a theory of sustainable entrepreneurship: Reducing environmental degradation through entrepreneurial action. Journal of business venturing, 22(1), 50-76.

Dean, T.J. \& McMullen, J.S. (2007). Toward a Theory of Sustainable Entrepreneurship: Reducing Environmental Degradation through Entrepreneurial Action. Journal of Business Venturing, 22(1), $50-76$.

Dees, J. G. (2017). The Meaning of Social Entrepreneurship. Case Studies in Social Entrepreneurship and Sustainability, 34-42. Available at https://communitywealth.org/sites/clone.community-wealth.org/files/downloads/paper-dees.pdf (accessed at 19 Nov 2019)

Garcia-Ruiz, J. M., Lasanta, T., Ruiz-Flano, P., Ortigosa, L., White, S., González, C., \& Martí, C. (1996). Land-use changes and sustainable development in mountain areas: a case study in the Spanish Pyrenees. Landscape Ecology, 11(5), 267-277

Hajer, M.A. (1995), The politics of environmental discourse: ecological modernization and the policy process (p. 40). Oxford: Clarendon Press

Hall, D. R. (1998). Tourism development and sustainability issues in Central and South-eastern Europe. Tourism Management, 19(5), 423-431.

Hill, T.L., Kothari, T.H. \& Shea, M. (2010). Patterns of meaning in the social entrepreneurship literature: A research platform. Journal of social entrepreneurship, 1(1), 5-31.

Hirotsune, K. (2011, March). Tourism, sustainable tourism and ecotourism in developing countries. In Proceedings of the ANDA International Conference, Nagoya, Japan (pp. 57).

Hostager, T.J., Neil, T.C., Decker, R.L., \& Lorentz, R.D. (1998). Seeing Environmental Opportunities: Effects of Intrapreneurial Ability, Efficacy, Motivation and Desirability, Journal of Organizational Change Management, 11(1), 11-25.

Intellecap. 2012. On the path to sustainability and scalability: A study of India's social enterprise landscape. Mumbai: Intellecap.

Keogh, P.D., \& Polonsky, M.J. (1998) 'Environmental Commitment: A Basis for Environmental Entrepreneurship?', Journal of Organizational Change Management, 11(1), 38-49. 
Kummitha, R. K. R., \& Majumdar, S. (2015). Dynamic curriculum development on social entrepreneurship-A case study of TISS. The International Journal of Management Education, 13(3), 260-267.

Kyrö, P. (2001) 'To Grow or Not to Grow? Entrepreneurship and Sustainable Development', International Journal of Sustainable Development and World Ecology, 8(1), 15-28.

Larson, A.L. (2000) 'Sustainable Innovation through an Entrepreneurship Lens',Business Strategy and the Environment, Wiley online library publications, 9, 304-317.

Lehner, O.M. (2011), The Phenomenon of Social Enterprise in Austria: A Triangulated Descriptive Study, Journal of Social Entrepreneurship, 2(1): 53-78

Lordkipanidze, M., Brezet, H., \& Backman, M. (2005). The entrepreneurship factor in sustainable tourism development. Journal of cleaner production, 13(8), 787-798.

McEwen, T. (2013), Ecopreneurship as a solution to environmental problems: implications for college level entrepreneurship education. International Journal of Academic Research in Business and Social Sciences, 3(5), 264.

Mol, A.P. (1996), Ecological modernization and institutional reflexivity: environmental reform in the late modern age. Environmental politics, 5(2), 302-323.

Muresan, I., Oroian, C., Harun, R., Arion, F., Porutiu, A., Chiciudean, G., ...Lile, R. (2016). Local residents' attitude toward sustainable rural tourism development. Sustainability, $8(1), 100$.

Pastakia, A. (2002). Assessing Ecopreneurship in the Context of a Developing Country: The Case of India, Greener Management International, 38 (Summer), 93-108

Richards, G., \& Hall, D. (Eds.). (2003). Tourism and sustainable community development (Vol. 7). Psychology Press.

Schaltegger, S. (2002) 'A Framework for Ecopreneurship: Leading Bioneers and Environmental Managers to Ecopreneurship', Greener Management International, 38 (Summer), 45-58.

Schaper, M. (2002). Introduction: The Essence of Ecopreneurship. Greener Management International, 2002(38), 26-30.

Schaper, M. (2002). The essence of ecopreneurship. Greener management international, 26-30.

Scheyvens, R. (1999). Ecotourism and the empowerment of local communities. Tourism Management, 20(2), 245-249.

Schumpeter, J.A. (1942) Capitalism, Socialism and Democracy. Vol. 36, Harper \& Row, New York, 132-145. Review Essay by Thomas K. McCraw, Harvard Business School.

Seelos, C., \& Mair, J. (2005) 'Social Entrepreneurship - The Contribution of Individual Entrepreneurs to Sustainable Development', IESE Business School Working Paper No. 553,

Stone, L. S., \& Stone, T. M. (2011). Community-based tourism enterprises: challenges and prospects for community participation; Khama Rhino Sanctuary Trust, Botswana. Journal of Sustainable Tourism, 19(1), 97-114.

Stronza, A. (2007). The economic promise of ecotourism for conservation. Journal of Ecotourism, 6(3), 210-230.

Tetzschner, H., \& Herlau, H. (2003). Innovation and Social Entrepreneurship in Tourism A Potential for Local Business Development (No. 49). Working Paper, Department of Environmental and Business Economics, University of Southern Denmark.

Thimm, T. (2017). The Kerala tourism model-an Indian state on the road to sustainable development. Sustainable Development, 25(1), 77-91.

Tilley, F., \& Young, W. (2009). Sustainability Entrepreneurs. Greener Management International, (55). 
Tol, R. S. (2018). The economic impacts of climate change. Review of Environmental Economics and Policy, 12(1), 4-25.

Tosun, C. (2000). Limits to community participation in the tourism development process in developing countries. Tourism management, 21(6), 613-633.

Van Rooyen, E. J. (2004). Sustainable agricultural development among the Southern Africa Development Community (SADC): considering integrated development planning practices and institutional arrangements. Journal of Public Administration, 39(Special issue 1), 558-573.

Véron R 2001. The 'new' Kerala model: lessons for sustainable development. World Development 29(4), 601-617.

Walley, E.E., \& Taylor, D. (2002) 'Opportunists, Champions, Mavericks...? A Typology of Green Entrepreneurs', Greener Management International, No. 38 (Summer), pp. 31-43.

WBCSD, The Sustainable Mobility Report 2002 Available at http://docs.wbcsd.org/2002/06/SustainableMobilityProject-ProgressReport2002.pdf (accessed at 20 Nov 2019)

Wearing, S., \& Neil, J. (2009). Ecotourism: impacts, potentials and possibilities? Elsevier, Linacre house, Jordan hill, oxford, UK second edition 2009

World Tourism Organization (2019), International Tourism Highlights, 2019 Edition, UNWTO, Madrid, DOI: https://doi.org/10.18111/9789284421152

Yaşar, S. A. R. I., \& Cemile, E. C. E. (2018). An Examination of Eco-village as an Example of Eco-entrepreneurship; The Case of Turkey. International Journal of Landscape Architecture Research (IJLAR) E-ISSN: 2602-4322, 2(2), 01-03.

York, J.G., O'Neil, I., \& Sarasvathy, S.D. (2016), Exploring environmental entrepreneurship: identity coupling, venture goals, and stakeholder incentives. Journal of Management Studies, 53(5), 695-737.

Zahra, S.A., Gedajlovic, E., Neubaum, D.O., \& Shulman, J.M. (2009). A typology of social entrepreneurs: Motives, search processes and ethical challenges. Journal of business venturing, 24(5), 519-532. 